\title{
Effects of alfalfa and cereal straw as a forage source on nutrient digestibility and lactation performance in lactating dairy cows
}

\author{
B. Wang, ${ }^{*}$ S. Y. Mao, † H. J. Yang, † Y. M. Wu, ${ }^{*}$ J. K. Wang, ${ }^{*}$ S. L. Li, $¥$ Z. M. Shen,† and J. X. Liu*1 \\ *Institute of Dairy Science, MoE Key Laboratory of Molecular Animal Nutrition, College of Animal Sciences, Zhejiang University, \\ Hangzhou 310058, P. R. China \\ †College of Animal Science and Technology, Nanjing Agricultural University, Nanjing 210095, P. R. China \\ ¥State Key Laboratory of Animal Nutrition, College of Animal Science and Technology, China Agricultural University, Beijing 100094, P. R. China
}

\begin{abstract}
This study was conducted to investigate the nutrient digestibility and lactation performance when alfalfa was replaced with rice straw or corn stover in the diet of lactating cows. Forty-five multiparous Holstein dairy cows were blocked based on days in milk $(164 \pm 24.8 \mathrm{~d}$; mean \pm standard deviation) and milk yield $(29.7 \pm 4.7$ $\mathrm{kg}$; mean \pm standard deviation) and were randomly assigned to 1 of 3 treatments. Diets were isonitrogenous, with a forage-to-concentrate ratio of 45:55 [dry matter (DM) basis] and contained identical concentrate mixtures and $15 \%$ corn silage, with different forage sources (on a DM basis): $23 \%$ alfalfa hay and $7 \%$ Chinese wild rye hay $(\mathrm{AH}), 30 \%$ corn stover (CS), and $30 \%$ rice straw (RS). The experiment was conducted over a 14wk period, with the first 2 wk for adaptation. The DM intake of the cows was not affected by forage source. Yield of milk, milk fat, protein, lactose, and total solids was higher in cows fed diets of AH than diets of RS or CS, with no difference between RS and CS. Contents of milk protein and total solids were higher in $\mathrm{AH}$ than in RS, with no difference between CS and AH or RS. Feed efficiency (milk yield/DM intake) was highest for cows fed $\mathrm{AH}$, followed by RS and CS. Cows fed AH excreted more urinary purine derivatives, indicating that the microbial crude protein yield may be higher for the $\mathrm{AH}$ diet than for RS and CS, which may be attributed to the higher content of fermentable carbohydrates in $\mathrm{AH}$ than in RS and CS. Total-tract apparent digestibilities of all the nutrients were higher in cows fed the $\mathrm{AH}$ diet than those fed CS and RS. The concentration of rumen volatile fatty acids was higher in the $\mathrm{AH}$ diet than in CS or RS diets, with no difference between CS and RS diets. When the cereal straw was used to replace alfalfa as a main forage source for lactating cows, the shortage of fermented energy may have reduced the rumen microbial protein synthesis, resulting in lower milk
\end{abstract}

Received January 18, 2014.

Accepted August 15, 2014.

${ }^{1}$ Corresponding author: liujx@zju.edu.cn protein yield, and lower nutrient digestibility may have restricted milk production.

Key words: forage source, lactation performance, nutrient digestibility

\section{INTRODUCTION}

Alfalfa is an excellent forage used for dairy cattle (Viands et al., 1988), but the availability of this feed ingredient is limited. In contrast, large amounts of crop residue such as corn stover and rice straw are produced each year, with approximately 200 million metric tonnes of corn stover and similar amounts of rice straw produced annually in China (Pang et al., 2008). However, the nutritional value of crop residues such as corn stover and rice straw is low because of the low contents of $\mathrm{CP}, \mathrm{ME}$, minerals, and vitamins, which may restrict their use as feed for dairy cows (Kebede, 2006; Zhao and $\mathrm{Li}, 2009$ ).

Milk yield and composition are affected by many factors, such as breed and nutritional factors, and a direct correlation exists between roughage intake and composition of milk yield (Sutton, 1989). Metabolizable protein is the main milk protein precursor and consists of microbial CP (MCP) synthesized in the rumen, dietary RUP, and endogenous protein (Clark et al., 1992). Microbial CP has well-balanced EAA and its yield is positively related to milk and milk protein yield (NRC, 2001; Zhu et al., 2013a). The efficiency of MCP synthesis in the rumen mainly depends on the availability of carbohydrates and N (Shabi et al., 1998). Maximizing MCP synthesis should increase the efficiency of $\mathrm{N}$ utilization and reduce $\mathrm{N}$ urinary excretion (Thomas, 1973). Alfalfa contains higher concentrations of soluble saccharides, NPN, easily available protein, RDP, RUP, and ME than rice straw and corn stover (NRC, 2001; Yari et al., 2012). The importance of readily fermentable carbohydrates to MCP yield has been documented (Lascano and Heinrichs, 2011). Dairy cows fed alfalfabased diets had better production performance compared with cows fed corn stover- or Chinese wild rye grass (Leymus chinensis) hay-based diets (Zhu et al., 
Table 1. Ingredients of the 3 experimental diets based on alfalfa, corn stover, and rice straw

\begin{tabular}{|c|c|c|c|}
\hline \multirow{2}{*}{$\begin{array}{l}\text { Ingredient, } \\
\% \text { of DM }\end{array}$} & \multicolumn{3}{|c|}{ Treatment $^{1}$} \\
\hline & $\mathrm{AH}$ & $\mathrm{CS}$ & $\mathrm{RS}$ \\
\hline Ground corn grain & 27.0 & 27.0 & 27.0 \\
\hline Wheat bran & 5.1 & 5.1 & 5.1 \\
\hline Soybean meal & 12.7 & 12.7 & 12.7 \\
\hline Cottonseed meal & 4.3 & 4.3 & 4.3 \\
\hline Beet pulp & 1.0 & 0.0 & 0.0 \\
\hline Corn silage & 15.0 & 15.0 & 15.0 \\
\hline Alfalfa hay & 23.0 & 0.0 & 0.0 \\
\hline Chinese wild grass hay & 7.0 & 0.0 & 0.0 \\
\hline Corn stover & 0.0 & 30.0 & 0.0 \\
\hline Rice straw & 0.0 & 0.0 & 30.0 \\
\hline Urea & 0.0 & 1.0 & 1.0 \\
\hline Premix $^{2}$ & 4.9 & 4.9 & 4.9 \\
\hline
\end{tabular}

2013a). The digestibility associated with ME supply may also be a pivotal factor for milk production. When crop residues of low quality are fed as a forage source, production performance of dairy cows is compromised (Kebede, 2006; Agbagla-Dohnani et al., 2012). However, little research has been conducted to compare alfalfa and cereal straw as a main forage source for the supply of readily fermentable carbohydrate, and lactation performance. Therefore, this study was conducted to investigate the nutrient digestibility and lactation performance when alfalfa was replaced with rice straw or corn stover in diets formulated for lactating cows.

\section{MATERIALS AND METHODS}

\section{Animals, Diets, and Experimental Design}

The use of the animals was approved by the Animal Care Committee, Zhejiang University (Hangzhou, China), and experimental procedures used in this study were in accordance with the university's guidelines for animal research. Forty-five multiparous Holstein dairy cows $(\mathrm{BW}=607 \pm 55.6 \mathrm{~kg}$, DIM $=164 \pm 24.8$, and milk yield $=29.7 \pm 4.7 \mathrm{~kg} / \mathrm{d}$; mean $\pm \mathrm{SD}$ ) were blocked into 15 groups based on DIM and milk production, and were randomly allocated to 1 of 3 dietary treatments (Table 1). Diets were formulated to be isonitrogenous with a forage-to-concentrate ratio of 45:55 (DM basis) and contained similar concentrate mixtures and $15 \%$ corn silage, with different forage sources (on a DM basis): (1) a diet containing $23 \%$ alfalfa hay and $7 \%$ Chinese wild rye hay (AH), (2) inclusion of 30\% corn stover replacing alfalfa hay and Chinese wild rye hay
(CS), and (3) inclusion of 30\% rice straw replacing alfalfa hay and Chinese wild rye hay (RS).

Diets were fed as TMR, which were mixed using a horizontal feed mixer (9SJW-300; National Science Makoto Farming Equipment Co. Ltd., Beijing, China). The experiment was conducted over 14 wk, with the first 2 wk for adaptation. Cows were housed in individually tethered stalls in a barn with good ventilation, and fed and milked 3 times daily at 0630, 1400, and $2000 \mathrm{~h}$ in a pipeline milking system. The cows had free access to drinking water.

\section{Sampling, Measurements, and Analyses of Feed, Milk, Feces, and Rumen Fluid}

During the 12 sampling weeks, milk production was recorded each week for the first 3 consecutive days, and milk samples were collected on the third day of each week using milk-sampling devices (Waikato Milking Systems NZ Ltd., Waikato, Hamilton, New Zealand). The amount of the feed offered was recorded every day and was adjusted to allow for 5 to $10 \%$ orts every week, and DMI was calculated based on the feed offered and orts. One $50-\mathrm{mL}$ aliquot of the milk sample was collected at each milking of the sampling day, proportional to the yield (4:3:3, composite). The composited milk sample, with added bronopol tablets (milk preservative, D \& F Control Systems, San Ramon, CA), was stored at $4^{\circ} \mathrm{C}$ for future analysis of protein, fat, lactose, MUN, TS, and SCC by infrared analysis (Laporte and Paquin, 1999) with a spectrophotometer (Foss-4000; Foss Electric A/S, Hillerød, Denmark). 
All diet ingredients were sampled weekly, and spot fecal samples (approximately $500 \mathrm{~g}$ ) were collected from the rectum of each cow 3 times per day at 0600, 1200, and $1800 \mathrm{~h}$ on the first $3 \mathrm{~d}$ of wk 6 and 10 during the sampling period. The samples were dried in a forced-air oven at $65^{\circ} \mathrm{C}$ for $48 \mathrm{~h}$ and stored in sealed plastic containers at $-4^{\circ} \mathrm{C}$ until analyses. The air-dried samples were ground through a 2-mm screen (Wiley Laboratory Mill; Arthur H. Thomas Co., Philadelphia, PA), and then through a 1-mm screen in a Cyclotec mill (Tecator 1093; Tecator AB, Höganäs, Sweden) before analysis of $\mathrm{DM}\left(105^{\circ} \mathrm{C}\right.$ for $\left.5 \mathrm{~h}\right)$, CP (method 988.05; AOAC, 1990), ash (method 942.05; AOAC, 1990), and ADF (method 973.18; AOAC, 1990). The NDF content was determined by the method of Van Soest et al. (1991) without sodium sulfite and amylase added. Starch content was determined using a colorimetric method (Weiss and Wyatt, 2000). Protein and carbohydrate fractions of the experimental diets were calculated using the determined chemical composition according to the Cornell Net Carbohydrate and Protein System (Cornell University, Ithaca, NY) model (Sniffen et al., 1992). The chemical composition of the individual forages is listed in Table 2 and the composition and protein and carbohydrate fractions in the Cornell Net Carbohydrate and Protein System of the experimental diets are listed in Table 3.

The total-tract apparent nutrient digestibility was determined using indigestible NDF (iNDF) as an internal marker based on the concentration of iNDF in the diet and feces, where iNDF (12-d ruminal incubation in $25-\mu \mathrm{m}$-pore-size bags) was determined according to the methods of Lee and Hristov (2013). Nutrient intake was calculated by the difference between specific nutrients in feed offered and orts.

On d 6 of wk 3,6, 9, and 12, rumen fluid samples (approximately $150 \mathrm{~mL}$ ) were collected approximately $3 \mathrm{~h}$ after morning feeding using an oral stomach tube (Shen et al., 2012). The $\mathrm{pH}$ was immediately measured using a portable $\mathrm{pH}$ meter (Starter 300; Ohaus Instruments Co. Ltd., Shanghai, China). The samples were placed on ice and kept stationary while the supernatant was separated and stored at $-20^{\circ} \mathrm{C}$ for future analysis of ammonia-N and VFA. Ammonia-N concentration was determined by steam distillation into boric acid and titration with dilute hydrochloric acid $(10 \mathrm{~mL})$. The VFA concentration was determined by gas chromatography (GC-8A; Shimadzu Corp., Kyoto, Japan), as described by $\mathrm{Hu}$ et al. (2005). Briefly, $2 \mu \mathrm{L}$ of supernatant, obtained from the fermentation medium by centrifuging at $13,000 \times g$ for $10 \mathrm{~min}$ at $4^{\circ} \mathrm{C}$, were injected into a $2-\mathrm{m} \times 3$-mm glass column packed with Porapak Q $(80$ mesh; Agilent Technologies Inc., Santa Clara, CA). The temperature of the injector/detector and the column were $200^{\circ} \mathrm{C}$ and $180^{\circ} \mathrm{C}$, respectively. Nitrogen was used as a carrier.

\section{In Situ Degradation}

In situ disappearance of $\mathrm{DM}$ and $\mathrm{CP}$ of the 3 diets was determined with 3 ruminally cannulated Holstein cows $(\mathrm{BW}=594 \pm 24.6 \mathrm{~kg}$, milk yield $=16.6 \pm 1.60$ $\mathrm{kg}$, and $\mathrm{DIM}=334 \pm 120.7 \mathrm{~d}$; mean $\pm \mathrm{SD}$ ) housed in individual stalls. The basal diet (\% of DM) consisted of $48.4 \%$ concentrate mixture, $16.9 \%$ corn silage, $27.7 \%$ alfalfa hay, and $6.9 \%$ Chinese wild rye grass hay fed 3 times daily for a total DMI of $1.5 \%$ of BW. The TMR samples used for in situ analysis were prepared according to the formulation of dietary treatments. The samples were then ground through a $3-\mathrm{mm}$ screen in a Wiley mill (Arthur H. Thomas Co.). The nylon bags (10 $\times 20 \mathrm{~cm} ; 50-\mu \mathrm{m}$ pore size; Ankom Technology Corp., Macedon, NY) containing $5 \mathrm{~g}$ of each sample were tied to the end of a 40-cm nylon line and then placed in the ventral sac of the rumen through ruminal cannula to incubate for $2,4,8,12,16,24,36$, and $48 \mathrm{~h}$. After removal from the rumen, the bags were rinsed thoroughly in cool running tap water until the wash water ran clear. The samples were dried in an oven at $65^{\circ} \mathrm{C}$ for $48 \mathrm{~h}$ and weighed to determine the residue mass. The residues and original diet samples were ground to pass through a $1-\mathrm{mm}$ screen in a Cyclotec mill (Teca-

Table 2. Nutrient composition (mean \pm SD) of forage components used in the experimental diets $(\mathrm{n}=5)$

\begin{tabular}{|c|c|c|c|c|c|}
\hline Composition & $\begin{array}{l}\text { Alfalfa } \\
\text { hay }\end{array}$ & $\begin{array}{l}\text { Corn } \\
\text { stover }\end{array}$ & $\begin{array}{l}\text { Rice } \\
\text { straw }\end{array}$ & $\begin{array}{l}\text { Chinese wild } \\
\text { grass hay }\end{array}$ & $\begin{array}{l}\text { Corn } \\
\text { silage }\end{array}$ \\
\hline DM, \% & $86.6 \pm 2.96$ & $83.7 \pm 3.31$ & $36.0 \pm 2.69$ & $84.1 \pm 4.02$ & $22.1 \pm 1.92$ \\
\hline $\mathrm{OM}, \%$ of $\mathrm{DM}$ & $93.8 \pm 0.51$ & $92.8 \pm 1.04$ & $86.4 \pm 0.94$ & $92.2 \pm 0.81$ & $94.7 \pm 0.77$ \\
\hline $\mathrm{CP}, \%$ of $\mathrm{DM}$ & $17.4 \pm 1.82$ & $5.9 \pm 0.85$ & $5.5 \pm 1.13$ & $8.1 \pm 1.16$ & $8.1 \pm 0.91$ \\
\hline $\mathrm{NDF}, \%$ of $\mathrm{DM}$ & $51.4 \pm 1.20$ & $74.1 \pm 2.21$ & $74.5 \pm 1.94$ & $64.5 \pm 5.74$ & $69.5 \pm 2.00$ \\
\hline $\mathrm{ADF}, \%$ of DM & $37.0 \pm 1.47$ & $39.7 \pm 2.66$ & $45.5 \pm 3.35$ & $37.9 \pm 2.28$ & $34 \pm 2.46$ \\
\hline $\mathrm{NFC},{ }^{1} \%$ of $\mathrm{DM}$ & $22.4 \pm 0.58$ & $11.6 \pm 0.35$ & $5.2 \pm 0.21$ & $15.7 \pm 0.56$ & $14.6 \pm 0.68$ \\
\hline $\mathrm{NE}_{\mathrm{L}},{ }^{2} \mathrm{Mcal} / \mathrm{kg}$ & 1.34 & 1.01 & 0.87 & 1.13 & 1.36 \\
\hline
\end{tabular}


Table 3. Nutrient compositions and carbohydrate and protein fractions (mean \pm SD) from the Cornell Net Carbohydrate and Protein System (CNCPS; Cornell University, Ithaca, NY) of the 3 experimental diets based on alfalfa, corn stover, and rice straw $(\mathrm{n}=5)$

\begin{tabular}{|c|c|c|c|}
\hline \multirow[b]{2}{*}{ Composition } & \multicolumn{3}{|c|}{ Treatment $^{1}$} \\
\hline & $\mathrm{AH}$ & CS & $\mathrm{RS}$ \\
\hline $\mathrm{DM}, \%$ & $52.9 \pm 2.68$ & $54.3 \pm 2.57$ & $51.4 \pm 2.25$ \\
\hline $\mathrm{OM}, \%$ of $\mathrm{DM}$ & $92.0 \pm 2.26$ & $91.7 \pm 1.69$ & $90.6 \pm 1.64$ \\
\hline $\mathrm{CP}, \%$ of DM & $16.7 \pm 0.22$ & $16.2 \pm 0.29$ & $16.0 \pm 0.46$ \\
\hline $\mathrm{NDF}, \%$ of $\mathrm{DM}$ & $31.1 \pm 1.73$ & $36.3 \pm 1.11$ & $36.9 \pm 1.26$ \\
\hline $\mathrm{ADF}, \%$ of $\mathrm{DM}$ & $18.9 \pm 1.07$ & $19.5 \pm 2.21$ & $21.9 \pm 2.53$ \\
\hline $\mathrm{NFC}^{2} \%$ of $\mathrm{DM}$ & $40.6 \pm 3.29$ & $36.0 \pm 2.29$ & $34.6 \pm 3.66$ \\
\hline $\mathrm{Ca}, \%$ of DM & $0.91 \pm 0.05$ & $0.62 \pm 0.06$ & $0.57 \pm 0.05$ \\
\hline $\mathrm{P}, \%$ of $\mathrm{DM}$ & $0.47 \pm 0.02$ & $0.45 \pm 0.03$ & $0.39 \pm 0.03$ \\
\hline $\mathrm{NE}_{\mathrm{L}},{ }^{3} \mathrm{Mcal} / \mathrm{kg}$ & 1.57 & 1.45 & 1.43 \\
\hline \multicolumn{4}{|c|}{ Carbohydrate fraction, ${ }^{4} \%$} \\
\hline $\mathrm{CA}$ & $22.2 \pm 1.75$ & $16.3 \pm 1.46$ & $14.4 \pm 3.45$ \\
\hline CB1 & $34.5 \pm 2.99$ & $29.0 \pm 2.37$ & $26.9 \pm 2.95$ \\
\hline CB2 & $28.2 \pm 3.14$ & $31.8 \pm 2.78$ & $34.4 \pm 2.37$ \\
\hline $\mathrm{CC}$ & $13.1 \pm 1.75$ & $14.3 \pm 1.37$ & $13.7 \pm 0.78$ \\
\hline \multicolumn{4}{|l|}{ CP fraction, ${ }^{4} \%$} \\
\hline PA & $25.4 \pm 1.66$ & $25.6 \pm 1.78$ & $23.1 \pm 2.12$ \\
\hline PB1 & $5.0 \pm 1.25$ & $3.0 \pm 0.35$ & $3.6 \pm 0.86$ \\
\hline PB2 & $60.6 \pm 2.30$ & $53.2 \pm 0.50$ & $57.6 \pm 2.44$ \\
\hline PB3 & $4.2 \pm 1.65$ & $14.7 \pm 1.05$ & $10.0 \pm 1.45$ \\
\hline $\mathrm{PC}$ & $4.8 \pm 0.71$ & $3.5 \pm 0.66$ & $5.7 \pm 0.67$ \\
\hline
\end{tabular}

${ }^{1} \mathrm{AH}=\mathrm{TMR}$ containing alfalfa hay as the main forage; CS = TMR containing corn stover as the main forage; $\mathrm{RS}=\mathrm{TMR}$ containing rice straw as the main forage.

${ }^{2} \mathrm{NFC}=100-\% \mathrm{NDF}-\% \mathrm{CP}-\%$ ether extract $-\%$ ash.

${ }^{3}$ Calculated based on Ministry of Agriculture of P. R. China recommendations (MOA, 2004).

${ }^{4}$ Calculated using the determined chemical compositions according to the CNCPS model (Sniffen et al., 1992). In the carbohydrate fraction, CA, CB1, CB2, and CC represent the soluble sugars and organic acids, starch and pectin, slowly fermented in the rumen by bacteria, and indigestible fiber, respectively; in the $\mathrm{CP}$ fraction, PA, PB1, PB2, PB3, and PC represent the soluble NPN, soluble true protein, protein with intermediate rates of degradation, protein insoluble in ND solution but soluble in AD solution, and unavailable $\mathrm{N}$, respectively.

tor 1093; Tecator AB) before analysis of the DM and $\mathrm{CP}$. The in situ degradation constants were estimated using the nonlinear model described by Ørskov et al. (1980): $P=a+b[1-\exp (-c t)]$, where $P=$ the rate of disappearance at time $t(\mathrm{~h}), a=$ the rapidly degradable fraction in the rumen, and $b=$ the fraction slowly degraded at rate $c(c>0)$. The effective degradability $(\mathbf{d g})$ was calculated by assuming a passage rate $(k p)$ of 4.6\%/h (Krizsan et al., 2010): $\mathrm{dg}=a+b c /(c+k p)$, where $a, b, c$, and $k p$ are the constants described above.

\section{Estimation of MCP and MP}

Urinary purine derivatives (PD) were used to indirectly estimate the MCP yield in the rumen (Chen and Gomes, 1992). Spot urine samples were collected every 2 wk before the 3 feeding times each day. Collected urine samples were pooled by cow, and $15 \mathrm{~mL}$ of each subsample was acidified with $60 \mathrm{~mL}$ of $0.036 \mathrm{~mol}$ of $\mathrm{H}_{2} \mathrm{SO}_{4} / \mathrm{L}$ and immediately stored at $-20^{\circ} \mathrm{C}$ for later analysis. The PD (allantoin and uric acid) were analyzed by the procedure of Chen and Gomes (1992) and creatinine was analyzed using a colorimetric picric acid assay (Oser, 1965). Creatinine has been validated as a marker to estimate urine volume (Leonardi et al., 2003) and was assumed to be excreted at a rate of $29 \mathrm{mg} / \mathrm{kg}$ of BW for calculating the urine volume excretion rate (Valadares et al., 1999).

The intestinally absorbable dietary protein (IADP) was estimated by the following equation: IADP $=$ RUP $\times$ CP intake $\times$ IDP, where IDP is the intestinal digestibility of RUP, determined from the residue of feedstuff incubated in the rumen for $16 \mathrm{~h}$, according to a modified 3-step procedure (Gargallo et al., 2006).

\section{Statistical Analysis}

Data on lactation performance, DMI, feed efficiency, $\mathrm{N}$ conversion, urine volume, urinary $\mathrm{PD}$, and rumen fermentation variables were analyzed using PROC MIXED of SAS (SAS Institute, 2000). A randomized complete block design with repeated measures was used, with week, diet, and interaction of diet by week as fixed effects and cow within diet as a random effect. The statistical model was as follows:

$$
\mathrm{Y}_{\mathrm{ijk}}=\mu+\mathrm{B}_{\mathrm{i}}+\mathrm{T}_{\mathrm{j}}+\mathrm{Wk}+\mathrm{TW}_{\mathrm{jk}}+\mathrm{E}_{\mathrm{ijk}}
$$


where $Y_{i j k}$ is dependent variable, $\mu$ is overall mean, $B_{i}$ is the random effect of block $\mathrm{i}, \mathrm{T}_{\mathrm{j}}$ is the diet effect, $\mathrm{Wk}$ is the week effect, $\mathrm{TW}_{\mathrm{jk}}$ is the interaction of diet and week, and $E_{\mathrm{ijk}}$ is the error term. For the repeatedmeasures analysis, the covariance structure with the least Akaike information criterion was used. Results were reported as least squares means.

In situ DM and CP degradation constants, dg, RUP, and intestinal digestion variables were analyzed using PROC GLM of SAS. The statistical model was the same as indicated above except that block, week and treat $\times$ week were omitted. Least squares means were calculated and separated using the PDIFF option of SAS. Differences between diets were detected using Duncan's adjustment. Statistical significance was defined at $P \leq 0.05$, with highly significant values at $P<$ 0.01 ; trends were declared at $0.05<P \leq 0.10$.

\section{RESULTS}

\section{Feed Intake and Milk Production Performance}

The results of feed intake and milk production performance are listed in Table 4. Feed intake was not affected by diet but it was affected by week $(P<0.01)$. In addition, the interaction of diet by week was significant $(P<0.01)$. Yields of milk, ECM, milk fat, milk protein, lactose, TS, and $\mathrm{N}$ conversion were higher for AH versus RS or CS diets $(P<0.01)$, with no difference between RS and CS diets $(P=0.15)$. Milk fat content was similar among the diets. The AH diet had higher $(P=0.01)$ content of milk protein and TS than the RS diet, with no difference between CS and RS or $\mathrm{AH}$ diets. Lower lactose percentage was observed for RS than the other 2 diets $(P<0.01)$, with no difference between $\mathrm{AH}$ and $\mathrm{CS}$ diets. A difference $(P<0.01)$ in feed efficiency (milk yield/DMI) was detected among the 3 diets, with the highest value for the $\mathrm{AH}$ diet, followed by RS and CS diets. The MUN concentration was lower $(P<0.01)$ for AH than for CS or RS diets. The effect of week was significant in the listed items except SCC. The milk yield decreased quickly during adaption of the first $2 \mathrm{wk}(P<0.01)$ and then had a slow decrease (Figure 1).

\section{Estimated MCP Yield and MP}

In Situ Rumen Degradation. The in situ rumen disappearance of DM and CP for the 3 diets is listed in Table 5. The CS diet had a lower $(P<0.05)$ soluble fraction ( $a$ value) of DM and $\mathrm{CP}$ but a higher $(P<$ $0.05)$ rate constant of DM degradation than the RS and $\mathrm{AH}$ diets. The dg value of DM was lower for the CS than for AH and RS diets $(P<0.05)$, whereas the $\mathrm{dg}$ of
$\mathrm{CP}$ (same as RDP) was lower for the AH diet than for $\mathrm{RS}$ and CS diets $(P<0.05)$. Thus, the RUP percentage of $\mathrm{CP}$ was higher $(P<0.05)$ for the $\mathrm{AH} \operatorname{diet}(54.8 \%)$ than for CS and RS diets, with no difference between these 2 diets.

Intestinal Digestibility of RUP and Estimated $\boldsymbol{M C P}$. The IDP, IADP, urinary PD, and estimated MCP and MP are listed in Table 6. No significant effects of diets on IDP $(P=0.62)$ were detected, but the IADP was higher for cows fed the AH than the CS diet (961 vs. 787; $P<0.05)$, with no difference $(P>0.05)$ between RS and AH or CS diets. The sum of urinary $\mathrm{PD}$ was higher for the $\mathrm{AH}$ diet than for RS and CS diets $(P=0.05)$; thus, the estimated MCP yield was calculated to be higher for the AH diet than for RS and CS diets (Table 6).

\section{Digestibility of Nutrients}

The total amount of nutrient intake and apparent total-tract nutrient digestibility are listed in Table 7 . The CP intake for the AH diet was higher $(P=0.04)$ for than for the RS diet, with no difference between CS and $\mathrm{AH}$ or RS diets. Compared with the $\mathrm{AH}$ diet, cows consuming $\mathrm{CS}$ and RS had greater $(P<0.01) \mathrm{NDF}$ intake. Total-tract apparent digestibilities of DM, OM, $\mathrm{NDF}$, and ADF were all higher for the AH diet than for CS and RS diets. No difference existed for the diet by week effect in the apparent digestibility. The week and diet by week effects on the nutrient intake were all highly significant $(P<0.01)$.

\section{Rumen Fermentation}

The rumen fermentation characteristics are listed in Table 8. No significant difference existed in rumen $\mathrm{pH}$ among the 3 diets $(P=0.76)$. Ammonia-N concentration was higher for the RS diet than for $\mathrm{AH}$ and CS diets $(P<0.01)$, with no difference between $\mathrm{CS}$ and $\mathrm{AH}$ diets. Total ruminal VFA concentration was higher $(P$ $=0.03$ or $P=0.02)$ in AH than in RS or CS diets, with no difference between RS and CS diets. The cows fed the $\mathrm{AH}$ diet had higher ruminal acetate concentration and molar proportion in total VFA $(P<0.01$ and $P$ $=0.02)$ than cows fed the CS diet, and higher ruminal propionate concentration $(P=0.04)$ than cows fed the $\mathrm{RS}$ diet. However, the molar proportion of propionate in total VFA was similar among the diets. Ruminal butyrate concentration and its molar proportion in total VFA was higher in CS $(P<0.01)$ than in AH and RS diets, with no difference between $\mathrm{AH}$ and $\mathrm{RS}$ diets.

\section{DISCUSSION}

The cows fed CS or RS in the place of AH did not reduce the DMI, even though the digestibility of the CS 


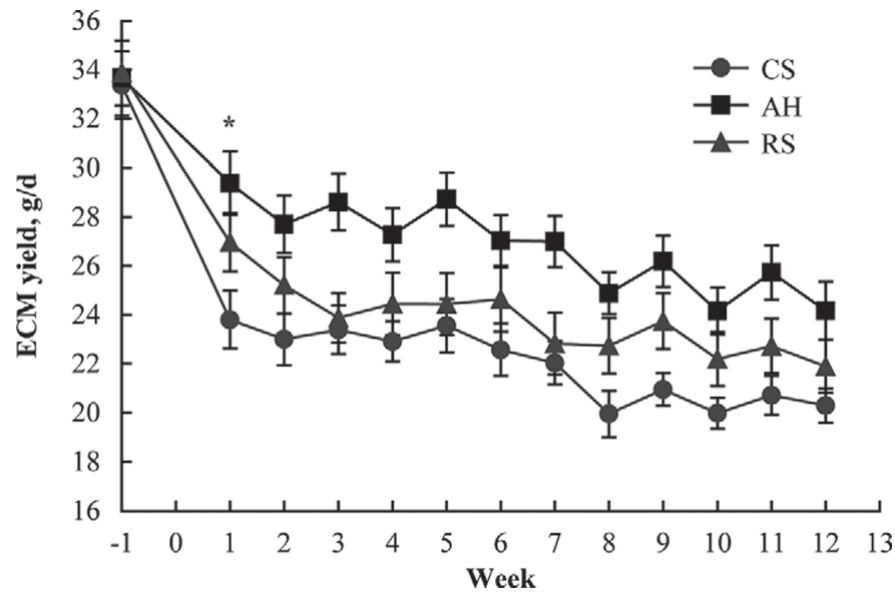

Figure 1. Change in ECM yield of lactating cows fed TMR with alfalfa hay $(\mathbf{A H})$, corn stover $(\mathbf{C S})$, and rice straw (RS) as main forage sources. The ECM in cows fed with the AH diet was higher than that in CS and RS diets during all 12 wk $(P<0.05)$. ${ }^{*}$ In the marked week, milk yield for the RS diet was higher than for the CS diet $(P<$ 0.05). Bars indicate the standard error.

or RS diet was lower. The lowered digestibility would reduce the feed intake, but it is dependent on the feed's energy density (Faverdin and Bareille, 1999). With a diet high in digestible energy, energy intake ceased to increase with ration digestibility (Conrad et al., 1964). Baumgardt (1970) indicated that when energy density is greater than $2.5 \mathrm{kcal} / \mathrm{kg}$ of DM, sheep adjust their intake accordingly. In the current study, the estimated $\mathrm{ME}(\mathrm{ME}=$ digestible $\mathrm{OM} \times 4.409 \times 0.82 ; \mathrm{NRC}, 2001)$ values for all diets were higher than $2.5 \mathrm{kcal} / \mathrm{kg}$ of DM. The cows fed the CS and RS diets with lower energy density may have consumed more DM than those on the $\mathrm{AH}$ diet to compensate for the need for more energy (Hayirli et al., 2002). Similar DMI among the 3 diets in the current study was consistent with Sun et al. (1994), who also observed a similar DMI when low-quality forage diets were compared with a diet in which lucerne composed $25 \%$ of the diet.

A higher milk yield in the AH diet resulted in the highest feed efficiency compared with CS and RS. Digestibility represents an important indicator for improving the efficiency of energy utilization in dairy cows (Reynolds et al., 2011). The ingredients and composition of diets fed to dairy cows affect nutrient digestibility and milk production performance (Weiss et al., 2009). The higher nutrient digestibility associated with higher milk yield was observed in the AH diet compared with CS and RS diets. Higher total concentration of ruminal VFA in AH-fed cows was indicative of the higher nutrient digestibility of the AH diet compared with CS and RS diets, suggesting increased energy supply to support milk production from the $\mathrm{AH}$ diet. Concentrate ingredients were similar among the 3 diets; thus, the differences were attributed to the forage source. These results indicate the importance of increasing nutrient

Table 4. Lactation performance and $\mathrm{N}$ conversion in dairy cows fed 3 experimental diets based on alfalfa, corn stover, and rice straw

\begin{tabular}{|c|c|c|c|c|c|c|c|}
\hline \multirow[b]{2}{*}{ Item } & \multicolumn{3}{|c|}{ Treatment $^{1}$} & \multirow[b]{2}{*}{ SEM } & \multicolumn{3}{|c|}{$P$-value ${ }^{2}$} \\
\hline & $\mathrm{AH}$ & CS & $\mathrm{RS}$ & & $\mathrm{T}$ & W & $\mathrm{T} \times \mathrm{W}$ \\
\hline DMI, kg/d & 18.0 & 18.2 & 18.0 & 0.18 & 0.64 & $<0.01$ & $<0.01$ \\
\hline \multicolumn{8}{|l|}{ Yield, $\mathrm{kg} / \mathrm{d}$} \\
\hline Milk & $23.5^{\mathrm{a}}$ & $19.4^{\mathrm{b}}$ & $20.8^{\mathrm{b}}$ & 0.52 & $<0.01$ & $<0.01$ & $<0.01$ \\
\hline $\mathrm{ECM}^{3}$ & $26.7^{\mathrm{a}}$ & $21.9^{\mathrm{b}}$ & $23.4^{\mathrm{b}}$ & 0.60 & $<0.01$ & $<0.01$ & 0.01 \\
\hline Fat & $0.98^{\mathrm{a}}$ & $0.82^{\mathrm{b}}$ & $0.88^{\mathrm{b}}$ & 0.025 & $<0.01$ & $<0.01$ & 0.04 \\
\hline Protein & $0.77^{\mathrm{a}}$ & $0.62^{\mathrm{b}}$ & $0.65^{\mathrm{b}}$ & 0.019 & $<0.01$ & $<0.01$ & $<0.01$ \\
\hline Lactose & $1.15^{\mathrm{a}}$ & $0.94^{\mathrm{b}}$ & $0.98^{\mathrm{b}}$ & 0.028 & $<0.01$ & $<0.01$ & $<0.01$ \\
\hline $\mathrm{TS}$ & $3.20^{\mathrm{a}}$ & $2.61^{\mathrm{b}}$ & $2.76^{\mathrm{b}}$ & 0.073 & $<0.01$ & $<0.01$ & $<0.01$ \\
\hline \multicolumn{8}{|c|}{ Milk composition, \% } \\
\hline Fat & 4.21 & 4.20 & 4.19 & 0.077 & 0.99 & $<0.01$ & 0.51 \\
\hline Protein & $3.30^{\mathrm{a}}$ & $3.20^{\mathrm{ab}}$ & $3.10^{\mathrm{b}}$ & 0.055 & 0.05 & $<0.01$ & 0.97 \\
\hline Lactose & $4.89^{\mathrm{a}}$ & $4.84^{\mathrm{a}}$ & $4.70^{\mathrm{b}}$ & 0.026 & $<0.01$ & $<0.01$ & 0.37 \\
\hline TS & $13.7^{\mathrm{a}}$ & $13.5^{\mathrm{ab}}$ & $13.2^{\mathrm{b}}$ & 0.15 & 0.13 & $<0.01$ & 0.83 \\
\hline MUN, mg/dL & $15.7^{\mathrm{b}}$ & $17.5^{\mathrm{a}}$ & $17.6^{\mathrm{a}}$ & 0.22 & $<0.01$ & $<0.01$ & $<0.01$ \\
\hline Feed efficiency ${ }^{4}$ & $1.31^{\mathrm{a}}$ & $1.07^{\mathrm{c}}$ & $1.16^{\mathrm{b}}$ & 0.025 & $<0.01$ & $<0.01$ & $<0.01$ \\
\hline $\mathrm{N}$ conversion ${ }^{5}$ & $25.1^{\mathrm{a}}$ & $20.4^{\mathrm{b}}$ & $21.6^{\mathrm{b}}$ & 0.54 & $<0.01$ & $<0.01$ & 0.07 \\
\hline $\mathrm{SCC}, \times 10^{3}$ & 657 & 535 & 383 & 93.2 & 0.13 & 0.18 & 0.95 \\
\hline
\end{tabular}

${ }^{\mathrm{a}-\mathrm{c}}$ Means within a row with different superscripts differ $(P<0.05)$.

${ }^{1} \mathrm{AH}=\mathrm{TMR}$ containing alfalfa hay as the main forage; $\mathrm{CS}=\mathrm{TMR}$ containing corn stover as the main forage;

$\mathrm{RS}=\mathrm{TMR}$ containing rice straw as the main forage.

${ }^{2} \mathrm{~T}=$ treatment effect; $\mathrm{W}=$ week effect; $\mathrm{T} \times \mathrm{W}=$ the interaction between treatment and week.

${ }^{3} \mathrm{ECM}(\mathrm{kg})=0.3246 \times$ milk yield $(\mathrm{kg})+13.86 \times$ fat yield $(\mathrm{kg})+7.04 \times$ protein yield $(\mathrm{kg})($ Orth, 1992).

${ }^{4}$ Feed efficiency $=$ milk yield/DMI.

${ }^{5} \mathrm{~N}$ conversion $=$ milk protein yield $/ \mathrm{CP}$ intake. 
Table 5. The DM and CP degradation constants based on the equation $P=a+b[1-\exp (-c t)]$, where $P=$ the rate of disappearance at time $t(\mathrm{~h}), a=$ the rapidly degradable fraction in the rumen, and $b=$ the fraction slowly degraded at rate $c(c>0)$; their effective degradability $(\mathrm{dg})$; and RUP of the 3 experimental diets based on alfalfa, corn stover, and rice straw

\begin{tabular}{|c|c|c|c|c|c|}
\hline \multirow[b]{2}{*}{ Item } & \multicolumn{3}{|c|}{ Treatment $^{1}$} & \multirow[b]{2}{*}{ SEM } & \multirow[b]{2}{*}{$P$-value } \\
\hline & $\mathrm{AH}$ & CS & $\mathrm{RS}$ & & \\
\hline \multicolumn{6}{|l|}{ DM degradation } \\
\hline$a, \%$ & $23.2^{\mathrm{a}}$ & $13.5^{\mathrm{b}}$ & $26.2^{\mathrm{a}}$ & 1.40 & 0.002 \\
\hline$b, \%$ & 56.8 & 51.7 & 55.8 & 5.94 & 0.82 \\
\hline$c, \% / \mathrm{h}$ & $3.1^{\mathrm{b}}$ & $6.6^{\mathrm{a}}$ & $3.4^{\mathrm{b}}$ & 0.70 & 0.022 \\
\hline $\mathrm{dg}^{2}$ & $46.1^{\mathrm{ab}}$ & $43.6^{\mathrm{b}}$ & $48.3^{\mathrm{a}}$ & 1.10 & 0.061 \\
\hline \multicolumn{6}{|l|}{$\mathrm{CP}$ degradation } \\
\hline$a, \%$ & $18.9^{\mathrm{b}}$ & $25.4^{\mathrm{a}}$ & $19.3^{\mathrm{b}}$ & 1.62 & 0.052 \\
\hline$b, \%$ & 69.1 & 56.2 & 63.8 & 2.20 & 0.017 \\
\hline$c, \% / \mathrm{h}$ & 2.9 & 3.8 & 4.1 & 0.48 & 0.26 \\
\hline $\mathrm{dg}^{2}$ & $45.2^{\mathrm{b}}$ & $50.5^{\mathrm{a}}$ & $49.0^{\mathrm{a}}$ & 1.04 & 0.029 \\
\hline $\mathrm{RUP}^{3} \%$ of $\mathrm{CP}$ & $54.8^{\mathrm{a}}$ & $49.5^{\mathrm{b}}$ & $51.0^{\mathrm{b}}$ & 1.04 & 0.029 \\
\hline
\end{tabular}

${ }^{\mathrm{a}, \mathrm{b}}$ Means within a row with different superscripts differ $(P<0.05)$.

${ }^{1} \mathrm{AH}=\mathrm{TMR}$ containing alfalfa hay as the main forage; $\mathrm{CS}=\mathrm{TMR}$ containing corn stover as the main forage; $\mathrm{RS}=\mathrm{TMR}$ containing rice straw as the main forage.

${ }^{2} \mathrm{dg}=a+b c /(c+k p)(\emptyset$ rskov et al., 1980), assuming a passage rate $(k p)$ of $4.6 \% / \mathrm{h}$ (Krizsan et al., 2010).

${ }^{3} \mathrm{RUP}=100-\mathrm{RDP}$.

digestibility for lactation performance in the cows fed cereal straw as a main forage source. Wanapat et al. (2009) observed that the increased nutrient intake and digestibility of rice straw by pretreatment with urea or urea plus calcium hydroxide was associated with improved lactation performance. Therefore, the digestion of crop residues should be improved to supply more available energy for milk synthesis when they are used for cows.
Milk protein secretion in dairy cows is closely associated with the supply of MP (NRC, 2001), whereas the energy supply is an important factor that affects the MCP synthesis and then milk protein yield (Zhu et al., 2013b). A significant relationship existed between milk protein yield and estimated MCP or MP (Zhu et al., 2013a). Our results indicate that both IADP and estimated MCP yield were higher in the cows fed AH (Table 6), contributing to a higher milk protein

Table 6. The intestinal $\mathrm{N}$ digestibility of the dietary protein, urinary purine derivatives (PD), and estimated MP supply to the dairy cows fed 3 experimental diets based on alfalfa, corn stover, and rice straw

\begin{tabular}{|c|c|c|c|c|c|}
\hline \multirow[b]{2}{*}{ Item } & \multicolumn{3}{|c|}{ Treatment $^{1}$} & \multirow[b]{2}{*}{ SEM } & \multirow[b]{2}{*}{$P$-value } \\
\hline & $\mathrm{AH}$ & CS & $\mathrm{RS}$ & & \\
\hline Urine volume,${ }^{2} \mathrm{~L} / \mathrm{d}$ & $26.8^{\mathrm{a}}$ & $25.7^{\mathrm{a}}$ & $21.2^{\mathrm{b}}$ & 1.38 & 0.02 \\
\hline \multicolumn{6}{|l|}{ Urinary PD, $\mathrm{mmol} / \mathrm{d}$} \\
\hline $\begin{array}{l}\text { Allantoin } \\
\text { Uric acid }\end{array}$ & $\begin{array}{r}394.0^{\mathrm{a}} \\
363^{\mathrm{a}}\end{array}$ & $\begin{array}{c}342.8^{\mathrm{aj}} \\
345^{\mathrm{a}}\end{array}$ & $\begin{array}{r}316.6^{\mathrm{b}} \\
23.6^{\mathrm{b}}\end{array}$ & $\begin{array}{r}25.86 \\
243\end{array}$ & 0.11 \\
\hline Endogenous PD & 47.3 & 48.1 & 47.2 & 0.79 & 0.65 \\
\hline $\mathrm{Sum}^{3}$ & $384.0^{\mathrm{a}}$ & $293.6^{\mathrm{ab}}$ & $298.8^{\mathrm{b}}$ & 30.00 & 0.05 \\
\hline $\mathrm{MCP}^{4} \mathrm{~g} / \mathrm{d}$ & 1,816 & 1,376 & 1,437 & 107.3 & \\
\hline IDP ${ }^{5} \%$ of RUP & 56.9 & 52.3 & 54.5 & 3.24 & 0.620 \\
\hline $\mathrm{IADP},{ }^{6} \mathrm{~g} / \mathrm{d}$ & $961^{\mathrm{a}}$ & $787^{\mathrm{b}}$ & $837^{\mathrm{ab}}$ & 38.7 & 0.047 \\
\hline
\end{tabular}

a,b Means within a row with different superscripts differ $(P<0.05)$.

${ }^{1} \mathrm{AH}=\mathrm{TMR}$ containing alfalfa hay as the main forage; $\mathrm{CS}=\mathrm{TMR}$ containing corn stover as the main forage; $\mathrm{RS}=\mathrm{TMR}$ containing rice straw as the main forage.

${ }^{2}$ Urine volume $(\mathrm{L} / \mathrm{d})=\mathrm{BW}(\mathrm{kg}) \times 29(\mathrm{mg} / \mathrm{d}) /$ creatinine $(\mathrm{mg} / \mathrm{L})$ (Valadares et al., 1999).

${ }^{3}$ Sum $=$ allantoin + uric acid - endogenous $\mathrm{PD}$.

${ }^{4}$ Microbial CP (MCP) was indirectly estimated by the equation (Chen and Gomes, 1992) MCP $=$ (allantoin + uric acid - endogenous PD) $\times 70 \times 6.25 /(0.116 \times 0.83 \times 1,000)$.

${ }^{5} \mathrm{IDP}=$ measured intestinal digestibility of RUP. The feedstuff incubated in the rumen for $16 \mathrm{~h}$ was used to determine the IDP according to a modified 3-step procedure (Gargallo et al., 2006).

${ }^{6}$ Intestinally absorbable dietary protein $(\mathrm{IADP})=\mathrm{RUP} \times \mathrm{CP}$ intake $\times$ IDP. 
Table 7. Total-tract apparent digestibility in dairy cows fed 3 experimental diets based on alfalfa, corn stover, and rice straw

\begin{tabular}{|c|c|c|c|c|c|c|c|}
\hline \multirow[b]{2}{*}{ Item } & \multicolumn{3}{|c|}{ Treatment $^{1}$} & \multirow[b]{2}{*}{ SEM } & \multicolumn{3}{|c|}{$P$-value ${ }^{2}$} \\
\hline & $\mathrm{AH}$ & CS & $\mathrm{RS}$ & & $\mathrm{T}$ & W & $\mathrm{T} \times \mathrm{W}$ \\
\hline \multicolumn{8}{|c|}{ Nutrient intake, $\mathrm{kg} / \mathrm{d}$} \\
\hline $\mathrm{OM}$ & 16.6 & 16.7 & 16.4 & 0.16 & 0.30 & $<0.01$ & $<0.01$ \\
\hline $\mathrm{CP}$ & $3.08^{\mathrm{a}}$ & $3.04^{\mathrm{ab}}$ & $3.01^{\mathrm{b}}$ & 0.023 & 0.11 & $<0.01$ & $<0.01$ \\
\hline NDF & $5.18^{\mathrm{b}}$ & $6.26^{\mathrm{a}}$ & $6.41^{\mathrm{a}}$ & 0.086 & $<0.01$ & $<0.01$ & $<0.01$ \\
\hline $\mathrm{ADF}$ & $3.40^{\mathrm{b}}$ & $3.46^{\mathrm{b}}$ & $3.91^{\mathrm{a}}$ & 0.039 & $<0.01$ & $<0.01$ & $<0.01$ \\
\hline \multicolumn{8}{|c|}{ Apparent digestibility, \% } \\
\hline DM & $60.0^{\mathrm{a}}$ & $51.2^{\mathrm{b}}$ & $48.3^{\mathrm{c}}$ & 0.62 & $<0.01$ & 0.98 & $<0.01$ \\
\hline $\mathrm{OM}$ & $62.9^{\mathrm{a}}$ & $55.9^{\mathrm{b}}$ & $51.0^{\mathrm{c}}$ & 1.38 & $<0.01$ & 0.44 & 0.39 \\
\hline $\mathrm{CP}$ & $62.4^{\mathrm{a}}$ & $57.2^{\mathrm{b}}$ & $54.9^{\mathrm{b}}$ & 0.90 & $<0.01$ & 0.68 & 0.01 \\
\hline NDF & $34.2^{\mathrm{a}}$ & $24.3^{\mathrm{b}}$ & $24.0^{\mathrm{b}}$ & 1.81 & $<0.01$ & $<0.01$ & 1.00 \\
\hline $\mathrm{ADF}$ & $28.4^{\mathrm{a}}$ & $14.4^{\mathrm{c}}$ & $18.3^{\mathrm{b}}$ & 1.13 & $<0.01$ & $<0.01$ & 0.89 \\
\hline
\end{tabular}

${ }^{\mathrm{a}-\mathrm{C}}$ Means within a row with different superscripts differ $(P<0.05)$.

${ }^{1} \mathrm{AH}=\mathrm{TMR}$ containing alfalfa hay as the main forage; $\mathrm{CS}=\mathrm{TMR}$ containing corn stover as the main forage; $\mathrm{RS}=\mathrm{TMR}$ containing rice straw as the main forage.

${ }^{2} \mathrm{~T}=$ treatment effect; $\mathrm{W}=$ week effect; $\mathrm{T} \times \mathrm{W}=$ the interaction between treatment and week.

yield compared with the CS and RS diets. Results on the effects of forage sources on the MCP synthesized in the rumen are inconsistent (Khorasani et al., 2001; Voelker Linton and Allen, 2009). Nocek and Russell (1988) found that a greater dietary concentration of NFC had a positive effect on the MCP yield, whereas a lower availability of readily fermentable carbohydrates decreased the MCP yield (Stern and Hoover, 1979; Lascano and Heinrichs, 2011). Compared with CS or RS, AH had higher portions of soluble carbohydrates (soluble sugars and organic acids, and starch and protein; Table 3), which may have increased the supply of the rumen fermentable energy for MCP synthesis. Therefore, it is critical to increase the supply of readily fermentable carbohydrates for MCP synthesis in the rumen when forage of low quality, such as cereal straw, is included in the diet of lactating cows.
Efficiency of $\mathrm{N}$ conversion from feed into milk is largely dependent on the capture of ammonia- $\mathrm{N}$ by the rumen microbes and utilization of the absorbed AA into milk protein (Tamminga, 1992). A lower rumen ammonia- $\mathrm{N}$ concentration associated with a lower MUN concentration in the $\mathrm{AH}$ diet means that $\mathrm{AH}$-fed cows had better synchronization of energy and $\mathrm{N}$ that was available for rumen microbes, which resulted in higher MCP yield (Herrera-Saldana et al., 1990; Landau et al., 2005). The supply of balanced AA is another factor in limiting milk protein yield (VandeHaar and St-Pierre, 2006). The higher supply of MP and AA in AH should also contribute to the improved $\mathrm{N}$ conversion compared with CS and RS. Further work is needed to improve the $\mathrm{N}$ conversion and increase milk protein for cereal straw diets by considering the balance of fermentable energy supply and AA.

Table 8. Ruminal pH, ammonia-N, and VFA in dairy cows fed 3 experimental diets based on alfalfa, corn stover, and rice straw

\begin{tabular}{|c|c|c|c|c|c|c|c|}
\hline \multirow[b]{2}{*}{ Item } & \multicolumn{3}{|c|}{ Treatment $^{1}$} & \multirow[b]{2}{*}{ SEM } & \multicolumn{3}{|c|}{$P$-value ${ }^{2}$} \\
\hline & $\mathrm{AH}$ & CS & $\mathrm{RS}$ & & $\mathrm{T}$ & $\mathrm{W}$ & $\mathrm{T} \times \mathrm{W}$ \\
\hline $\mathrm{pH}$ & 6.41 & 6.37 & 6.38 & 0.039 & 0.76 & $<0.01$ & $<0.01$ \\
\hline Ammonia-N, mg/dL & $15.4^{\mathrm{b}}$ & $16.3^{\mathrm{b}}$ & $20.1^{\mathrm{a}}$ & 1.06 & 0.02 & $<0.01$ & 0.18 \\
\hline Total VFA. $\mathrm{m} M$ & $92.3^{\mathrm{a}}$ & $85.5^{\mathrm{b}}$ & $85.3^{\mathrm{b}}$ & 1.96 & 0.03 & $<0.01$ & 0.01 \\
\hline Acetate, $\mathrm{m} M$ & $65.4^{\mathrm{a}}$ & $58.4^{\mathrm{b}}$ & $61.7^{\mathrm{ab}}$ & 1.40 & 0.01 & $<0.01$ & 0.59 \\
\hline Propionate, $\mathrm{m} M$ & $19.1^{\mathrm{a}}$ & $18.0^{\mathrm{ab}}$ & $17.3^{\mathrm{b}}$ & 0.58 & 0.12 & $<0.01$ & $<0.01$ \\
\hline Butyrate, $\mathrm{m} M$ & $7.52^{\mathrm{b}}$ & $9.33^{\mathrm{a}}$ & $6.38^{\mathrm{b}}$ & 0.483 & $<0.01$ & $<0.01$ & $<0.01$ \\
\hline \multicolumn{8}{|l|}{ Molar proportion, $\mathrm{m} M / 100 \mathrm{~m} M$} \\
\hline Acetate & $71.0^{\mathrm{a}}$ & $68.4^{\mathrm{b}}$ & $72.7^{\mathrm{a}}$ & 0.71 & $<0.01$ & $<0.01$ & $<0.01$ \\
\hline Propionate & 20.8 & 21.1 & 20.1 & 0.55 & 0.39 & 0.13 & $<0.01$ \\
\hline Butyrate & $8.1^{\mathrm{b}}$ & $10.5^{\mathrm{a}}$ & $7.3^{\mathrm{b}}$ & 0.46 & $<0.01$ & $<0.01$ & $<0.01$ \\
\hline Acetate:propionate & $3.46^{\mathrm{ab}}$ & $3.36^{\mathrm{b}}$ & $3.68^{\mathrm{a}}$ & 0.086 & 0.05 & $<0.01$ & $<0.01$ \\
\hline
\end{tabular}

$\overline{\mathrm{a}, \mathrm{b}}$ Means within a row with different superscripts differ $(P<0.05)$.

${ }^{1} \mathrm{AH}=\mathrm{TMR}$ containing alfalfa hay as the main forage; $\mathrm{CS}=\mathrm{TMR}$ containing corn stover as the main forage; $\mathrm{RS}=\mathrm{TMR}$ containing rice straw as the main forage.

${ }^{2} \mathrm{~T}=$ treatment effect; $\mathrm{W}=$ week effect; $\mathrm{T} \times \mathrm{W}=$ the interaction between treatment and week. 


\section{CONCLUSIONS}

The AH diet had higher nutrient digestibility, resulting in a higher energy supply for lactation and, hence, higher milk and milk protein yield than for the cows consuming CS and RS diets. Higher content of easily fermented carbohydrate and RUP contributed to the higher MP in AH than in CS or RS diets; thus, milk protein yield was higher in $\mathrm{AH}$ than in CS or RS diets, with no difference between CS and RS diets.

\section{ACKNOWLEDGMENTS}

This research was supported by grants from the National Basic Research Program of the China Ministry of Science and Technology (Beijing, China; No. 2011CB100801) and from the China Agricultural Research System (Beijing, China; No. CARS-37). The authors gratefully thank the personnel of Hangjiang Dairy Farm (Hangzhou, China) for their assistance in feeding and care of the animals. We also acknowledge the members of the Institute of Dairy Science at Zhejiang University (Hangzhou, China) for their assistance in the sampling and analysis of the samples. Special thanks go to Huizeng Sun from Zhejiang University, Longhui Jing from Nanjing Agricultural University (Nanjing, China), and Binbin Cao from China Agricultural University (Beijing, China) for their assistance in feeding of the animals and sampling.

\section{REFERENCES}

Agbagla-Dohnani, A., A. Cornu, and L. P. Broudiscou. 2012. Rumen digestion of rice straw structural polysaccharides: Effect of ammonia treatment and lucerne extract supplementation in vitro. Animal 6:1642-1647.

AOAC (Association of Official Analytical Chemists). 1990. Official Methods of Analysis. 15th ed. AOAC, Arlington, VA.

Baumgardt, B. R. 1970. Control of feed intake in the regulation of energy balance. Pages 235-253 in Physiology of Digestion and Metabolism in the Ruminant. A. T. Philipson, ed. Oriel Press, Newcastle, UK.

Chen, X. B., and M. J. Gomes. 1992. Estimation of microbial protein supply to sheep and cattle based on urinary excretion of purine derivatives: An overview of technical details. Int. Feed Res. Unit, Occasional Publ. Rowett Research Institute, Aberdeen, UK.

Clark, J. H., T. H. Klusmeyer, and M. R. Cameron. 1992. Microbial protein synthesis and flows of nitrogen fractions to the duodenum of dairy cows. J. Dairy Sci. 75:2304-2323.

Conrad, H. R., A. D. Pratt, and J. W. Hibbs. 1964. Regulation of food intake in dairy cows. 1. Change in importance of physical and physiological factors with increasing digestibility. J. Dairy Sci. $47: 54-62$

Faverdin, P., and N. Bareille. 1999. Lipostatic regulation of feed intake in ruminants. Pages 88-102 in Regulation of Feed Intake. D. van der Heide, E. A. Huisman, E. Kanis, J. W. M Osse, and M. Verstegen, ed. CAB International, Wallingford, UK.

Gargallo, S., S. Calsamiglia, and A. Ferret. 2006. Technical note: A modified three-step in vitro procedure to determine intestinal digestion of proteins. J. Anim. Sci. 84:2163-2167.
Hayirli, A., R. R. Grummer, E. V. Nordheim, and P. M. Crump. 2002 Animal and dietary factors affecting feed intake during the prefresh transition period in Holsteins. J. Dairy Sci. 85:3430-3443.

Herrera-Saldana, R., R. Gomez-Alarcon, M. Torabi, and J. T. Huber. 1990. Influence of synchronizing protein and starch degradation in the rumen on nutrient utilization and microbial protein synthesis. J. Dairy Sci. 73:142-148.

Hu, W.-L., J.-X. Liu, J.-A. Ye, Y.-M. Wu, and Y.-Q. Guo. 2005. Effect of tea saponin on rumen fermentation in vitro. Anim. Feed Sci. Technol. 120:333-339.

Kebede, G. 2006. Effect of urea-treatment and leucaena (Leucaena leucocephala) supplementation on the utilization of wheat straw as feed for sheep. MS Thesis. Haramaya Univ., Haramaya, Ethiopia.

Khorasani, G. R., E. K. Okine, and J. J. Kennelly. 2001. Effects of forage source and amount of concentrate on rumen and intestinal digestion of nutrients in late-lactation cows. J. Dairy Sci. 84:1156-1165.

Krizsan, S. J., S. Ahvenjärvi, and P. Huhtanen. 2010. A meta-analysis of passage rate estimated by rumen evacuation with cattle and evaluation of passage rate prediction models. J. Dairy Sci. 93:5890-5901

Landau, S., D. Kababya, N. Silanikove, R. Nitsan, L. Lifshitz, H. Baram, I. Bruckental, and S. J. Mabjeesh. 2005. The ratio between dietary rumen degradable organic matter and crude protein may affect milk yield and composition in dairy sheep. Small Rumin. Res. 58:115-122.

Laporte, M. F., and P. Paquin. 1999. Near-infrared analysis of fat, protein, and casein in cow's milk. J. Agric. Food Chem. 47:26002605.

Lascano, G. J., and A. J. Heinrichs. 2011. Effects of feeding different levels of dietary fiber through the addition of corn stover on nutrient utilization of dairy heifer precision-fed high and low concentrate diets. J. Dairy Sci. 94:3025-3036.

Lee, C., and A. N. Hristov. 2013. Short communication: Evaluation of acid-insoluble ash and indigestible neutral detergent fiber as total-tract digestibility markers in dairy cows fed corn silage-based diets. J. Dairy Sci. 96:5295-5299.

Leonardi, C., M. Stevenson, and L. E. Armentano. 2003. Effect of two levels of crude protein and methionine supplementation on performance of dairy cows. J. Dairy Sci. 86:4033-4042.

MOA (Ministry of Agriculture of P.R. China). 2004. Feeding Standard of Dairy Cattle (NY/T 34-2004). MOA, Beijing, China.

Nocek, J. E., and J. B. Russell. 1988. Protein and energy as an integrated system: Relationship of ruminal protein and carbohydrate availability to microbial synthesis and milk production. J. Dairy Sci. 71:2070-2107.

NRC. 2001. Nutrient requirements of dairy cattle. 7th rev. ed. Natl. Acad. Sci., Washington, DC.

Ørskov, E. R., F. D. DeB Hovell, and F. Mould. 1980. The use of the nylon bag technique for the evaluation of feedstuffs. Trop. Anim. Prod. 5:195-213.

Orth, R. 1992. Sample day and lactation report, DHIA 200. Fact Sheet A-2. Mid-States Dairy Records Processing Center (DRPC), Ames, IA.

Oser, B. L. 1965. Hawk's Physiological Chemistry. 14th ed. McGrawHill, New York, NY.

Pang, Y. Z., Y. P. Liu, X. J. Li, K. S. Wang, and H. R. Yuan. 2008. Improving biodegradability and biogas production of corn stover through sodium hydroxide solid state pretreatment. Energy Fuels $22: 2761-2766$

Reynolds, C. K., L. A. Crompton, and J. A. N. Mills. 2011. Improving the efficiency of energy utilisation in cattle. Anim. Prod. Sci. 51:6-12.

SAS Institute. 2000. SAS User's Guide: Statistics. Version 8.01. SAS Inst. Inc., Cary, NC.

Shabi, Z., A. Arieli, I. Bruckental, Y. Aharoni, S. Zamwel, A. Bor, and H. Tagari. 1998. Effect of the synchronization of the degradation of dietary crude protein and organic matter and feeding frequency on ruminal fermentation and flow of digesta in the abomasum of dairy cows. J. Dairy Sci. 81:1991-2000. 
Shen, J. S., Z. Chai, L. J. Song, J. X. Liu, and Y. M. Wu. 2012. Insertion depth of oral stomach tubes may affect the fermentation parameters of ruminal fluid collected in dairy cows. J. Dairy Sci. 95:5978-5984.

Sniffen, C. J., J. D. O'Connor, P. J. Van Soest, D. G. Fox, and J. B. Russell. 1992. A net carbohydrate and protein system for evaluating cattle diets. 2. Carbohydrate and protein availability. J. Anim. Sci. 70:3562-3577.

Stern, M. D., and W. H. Hoover. 1979. Methods for determining and factors affecting rumen microbial protein synthesis: A review. J. Anim. Sci. 49:1590-1603.

Sun, W., A. L. Goetsch, L. A. Forster Jr., D. L. Galloway Sr., and P. K. Lewis Jr. 1994. Forage and splanchnic tissue mass in growing lambs: effects of dietary forage levels and source on splanchnic tissue mass in growing lambs. Br. J. Nutr. 71:141-151.

Sutton, J. D. 1989. Altering milk composition by feeding. J. Dairy Sci. $72: 2801-2814$.

Tamminga, S. 1992. Nutrition management of dairy cows as a contribution to pollution control. J. Dairy Sci. 75:345-357.

Thomas, P. C. 1973. Microbial protein synthesis. Proc. Nutr. Soc. 32:85-91.

Valadares, R. F. D., G. A. Broderick, S. C. Valadares Filho, and M. K. Clayton. 1999. Effect of replacing alfalfa silage with high moisture corn on ruminal protein synthesis estimated from excretion of total purine derivatives. J. Dairy Sci. 82:2686-2696.

Van Soest, P. J., J. B. Robertson, and B. A. Lewis. 1991. Methods for dietary fiber, neutral detergent fiber, and nonstarch polysaccharides in relation to animal nutrition. J. Dairy Sci. 74:3583-3597.

VandeHaar, M. J., and N. St-Pierre. 2006. Major advances in nutrition: Relevance to the sustainability of the dairy industry. J. Dairy Sci. 89:1280-1291.

Viands, D. R., P. Sun, and D. K. Barnes. 1988. Pollination control: Mechanical and sterility. Pages 931-960 in Alfalfa and Alfalfa Im- provement (Agronomy). A. A. Hanson, D. K. Barnes, and R. R. Hill Jr., ed. Am. Soc. Agron., Crop Sci. Soc. Am., Soil Sci. Soc. Am., Madison, WI.

Voelker Linton, J. A., and M. S. Allen. 2009. Nutrient demand interacts with forage family to affect nitrogen digestion and utilization responses in dairy cows. J. Dairy Sci. 92:1594-1602.

Wanapat, M., S. Polyorach, K. Boonnop, C. Mapato, and A. Cherdthong. 2009. Effects of treating rice straw with urea or urea and calcium hydroxide upon intake, digestibility, rumen fermentation and milk yield of dairy cows. Livest. Sci. 125:238-243.

Weiss, W. P., N. R. St-Pierre, and L. B. Willett. 2009. Varying type of forage, concentration of metabolizable protein, and source of carbohydrate affects nutrient digestibility and production by dairy cows. J. Dairy Sci. 92:5595-5606.

Weiss, W. P., and D. J. Wyatt. 2000. Effect of oil content and kernel processing of corn silage on digestibility and milk production by dairy cows. J. Dairy Sci. 83:351-358.

Yari, M., R. Valizadeh, A. A. Naserian, G. R. Ghorbani, P. Rezvani Moghaddam, A. Jonker, and P. Yu. 2012. Botanical traits, protein and carbohydrate fractions, ruminal degradability and energy contents of alfalfa hay harvested at three stages of maturity and in the afternoon and morning. Anim. Feed Sci. Technol. 172:162-170.

Zhao, T. Z., and H. Y. Li. 2009. Study on ruminal degradation of mainly protein and fiber sources in dairy diets. Contemp. Anim. Husb. 11:29-32.

Zhu, W., Y. Fu, B. Wang, C. Wang, J. A. Ye, Y. M. Wu, and J.-X. Liu. 2013a. Effects of dietary forage sources on rumen microbial protein synthesis and milk performance in early lactating dairy cows. J. Dairy Sci. 96:1727-1734.

Zhu, W., C. Tang, X. Sun, J. Liu, Y. Wu, Y. Yuan, and X. Zhang. 2013b. Rumen microbial protein synthesis and milk performance in lactating dairy cows fed the fortified corn stover diet in comparison with alfalfa diet. J. Anim. Vet. Adv. 12:633-639. 